\title{
The perceptions of school administrators concerning "merit" concept: A metaphor study
}

\author{
Ramazan Gök \\ Akdeniz University, Faculty of Education, Turkey
}

\begin{abstract}
The aim of this study is to evaluate the perceptions of school principals and teachers about the concept of merit by means of metaphors. Metaphor has been used as a data collection method. The research data were obtained from 185 administrators working in public primary and secondary schools in five central districts of Antalya/Turkey. Easily accessible case sampling, one of the purposeful sampling methods, was used to determine the study group. The data were subjected to inductive content analysis by using metaphorical analysis. One hundred and nine metaphors produced by the participants were used in the analysis process. The findings show that the participants mostly likened the concept of merit to scale, tree, mother, ant, driving license, dress, ladder, car, and water. As a result, it is seen that the participants consider the concept of merit in the context of their hierarchical status and associate them with the features that managers should have. On the whole, school administrators explained the concept of merit in terms of suitability to the task, being capable, fair, indispensable, open to development, diligent, integrative, original and visionary, and being focused on career steps. In particular, it is important that competent managers are seen as people who give confidence to their environment, make the right decisions, and act as mentors. In addition, the perception of merit as a means of promotion in career steps is another important result of the study.
\end{abstract}

Keywords: Merit; Metaphor; School administrator; Public school

Article History: Submitted 27 March 2020; Revised 1 September 2020; Published online 28 October 2020

\section{Introduction}

School administrators and teachers are among the people who are responsible for using all available resources and achieving the highest level of efficiency in order to achieve the objectives of national education. School management is the most effective placement or use of human resources in order to achieve the aims of the institutions and schools related to education (Binbaşığlu, 1978). According to Kaya (1999), a school administrator has to establish relationships with people with different expectations from different educational and cultural levels, such as teachers, staff, students, parents, environmental leaders, local administrators, and central organization and politicians, and to maintain democratic governance by harmonizing their contradictory expectations.

Address of Corresponding Author

Ramazan Gök, PhD, Akadeniz University, Faculty of Education, Kampus, Konyaaltı, Antalya, 07058, Turkey.

$\triangle$ ramazangok@akdeniz.edu.tr

0000-0002-5342-8971

How to cite: Gök, R. (2020). The perceptions of school administrators concerning "merit" concept: A metaphor study. Journal of Pedagogical Research, 4(3), 299-311. 


\subsection{Merit}

The principles of merit, which means a person's eligibility to be given a job and their worthiness (Turkish Language Association [TLA], 2019), were first introduced in Germany in the first half of the eighteenth century by Friedrich II of Prussia. He, along with the principles of merit, accepted the method of education and examination at the entrance to the civil service (Günay, 2005). With the reintegration system carried out in the Ottoman Empire, the merit system worked well until the period after Suleiman the Magnificent, and even a peasant child with good merit could rise to the highest position. Thus, favoritism of large families or considerable people was prevented. After Suleiman the Magnificent, favoritism and nepotism increased and merit began to move away. The deterioration of the merit system has been one of the reasons for the collapse of the Ottoman Empire. The Ottoman Empire, which adopted the principle of equality with the Tanzimat Edict, made the merit principle with the first constitution, Kanun-i Esasi, a constitutional rule (Y1ld1z, 2016).

With the establishment of the Republic, no system like Enderun was established, but legal arrangements were put into practice to ensure adequacy and seniority (Y1ldiz, 2016). In the third article of the Civil Servants Law No. 657, the principles of "classification", "career", and "merit" regarding the employment of civil servants are included. The merit principle is defined in the law as follows: "to base the merit system on entering the state public service duties, promotion and career advancement within the classes, the termination of the task and to ensure the security of the Civil Servants in the implementation of this system with equal opportunities" (State Personnel Law [SPL], 1965). In short, the merit system ensures that the public service is carried out with the highest quality for both the governors and the governed.

The merit principle is not only a principle to be considered when appointing a person to a civil service. It is essential for the person to comply with this principle during his/her service (Bucaktepe, 2014). In order to be able to apply the merit system, it is important to select and hire people who are most suitable for the task and who have the power to perform that task (Ergun, 2004). However, in the merit system based on the principles of equality, career, a fair and adequate wage, and in-service evaluation (Sezer, 2003), one's competence should not be the sole quality that is focused upon. All rights and interests of the person and working conditions should be matched with competence and suitability (Ateş, 1995).

The two main conditions of the merit system are service compliance and impartiality. In the process of recruitment or promotion in a public office, examinations are the most important tool used by the administration in decision-making. Therefore, the eligibility criteria for the service are assessed through "examination" practices (Diler, 2018). The most appropriate means of realizing the merit principle are "open competition" exams. The aim is to bring the most suitable people to public tasks through competition exams. It is also a method developed to prevent political nepotism. In order to be realistic about the concept of open competition exams, certain principles must be followed, and the exam should be conducted within those conditions (Aykaç, 1990; Tortop, 1982).

The references from the person's previous experience, the opinions of the advisers, and the observation and testing of the employee's active work for a certain period of time provide the collection of the most important data about his/her merit. It is a typical merit approach to conduct archive scans and security investigations of people who aspire to work in a public office (Günay \& Çarıkçı, 2019). School administrators who should act as role models to their teachers by expressing themselves, behaving objectively, and being sincere should also have merit and come to deserve their position. Otherwise, it will be difficult for school administrators to gain their respect (Akbaşli \& Diş, 2019).

When examples from countries across the world are evaluated, it is seen that a country's merit principle is a must for the personnel system (Sayan, 2017). The skills required to be merited are grouped into three items: technical, interpersonal, and conceptual skills (Hoy \& Miskel, 2010): 
- Having specific knowledge of a particular job, activity, pathway, or completion technique is a technical skill.

- Interpersonal skills are the ability to communicate orally and in writing, to be social, and to form empathy.

- Conceptual or cognitive abilities include analytical and logical thinking; reasoning, such as induction and deduction; and the ability to work with these concepts.

In literature, different studies on the merit system have been conducted. In one of these studies, $\mathrm{Uz}$ (2011) examined the legal framework of the merit principle. He emphasized the necessity of ensuring the implementation of the merit principle in a country, rather than its existence or regulation. In another study, Özdemir (2013) investigated the relationship between justice and merit in school principals and loyalty and effort in teachers and concluded that if there is a sense of what is right and just in managers, employees have the loyalty and determination to work.

Şahin (2016), working on the concepts of contemporary merit in recruitment and promotion in the public personnel system, investigated the position of developed countries and our country in the public administration systems and identified possible problems and offered solutions. In addition, the effective merit system (Şahin \& Şahin, 2016), the merit system applications in the Turkish Public Administration after Republic (Gökdeniz et al., 2017), and the merit principle in public administration (Karatepe \& Kurnaz, 2019) were the other conspicuous studies.

\subsection{Metaphor}

According to Morgan (1998, as cited in Evcim, 2008), the use of metaphors is the concept of planning and visualization of the world, taking into consideration our understanding of the world in general. In this respect, metaphor is a powerful mental tool that an individual can use to understand and explain a highly abstract, complex, or theoretical phenomenon.

Metaphor is a tool of perception (Arnett, 1999). Lakoff and Johnson (2008) stated that metaphors are the main linguistic tools discovered by human beings in order to understand, explain, establish, and organize the world. Therefore, they stated that metaphors will help to comprehend how people construct their own reality and how they perceive the world (Saban et al., 2006; Semerci, 2007).

According to Arslan and Bayrakçı (2006), metaphors are a powerful mental mapping and modeling mechanism for individuals to understand and construct their own worlds. The metaphor highlights some comments and pushes others into the background. In other words, the way of seeing it created also becomes a form of not seeing. Thus, the metaphor of "human is a lion" draws attention to the lion's courage, power, or predatory nature while suggesting the fact that the same person may be a demon, a saint, or a hermit. Metaphor pushes us to see similarities and to ignore different aspects. The metaphor expands imagination to provide powerful insights, but it also carries the danger of distortion (Morgan, 1998, as cited in Evcim, 2008). The level of competence and performance expected from school administrators is closely observed by teachers and by the administrators themselves. Consequently, the behaviors of the school administrators reveal their merit levels, and these levels are perceived, monitored, and made meaningful by the groups they are in contact with. When the expressions formed in the mind are expressed in some way, they can be noticed by other people. There are several ways to express mental perceptions. One of these different forms of meaning and expression is "metaphors" (Akın-Kösterelioğlu, 2014). There are no studies on the evaluation of perceptions about merit concept with metaphors.

The aim of this study is to evaluate the perceptions of school administrators and teachers about merit concept by means of metaphors. In order to achieve this aim, school principals' and teachers' metaphors about merit concept were determined. 


\section{Method}

\subsection{Research Design}

In this study, which aimed to determine in-depth perceptions of school administrators and teachers regarding the concept of merit, phenomenology design, one of the qualitative research designs, was used. According to Büyüköztürk et al. (2010), qualitative research methods are appropriate approaches in the study of human perceptions. Phenomenology studies, on the one hand, try to determine the perceptions and reactions of individuals against an event in a detail way (Fraenkel et al., 2011). In other words, the phenomenon is focused on phenomena that we are aware of, but we do not have an in-depth and detailed understanding of (Yıldırım \& Şimşek, 2011). At the same time, the study was conducted on the basis of a cognitive theory related to metaphors, since metaphors were used as data collection tools (Tepebaşıl1, 2013).

\subsection{Participants}

The study group consists of 185 administrators and teachers working in public primary and secondary schools in five central districts of Antalya. In order to reach more participants for the study group, easily accessible case sampling, one of the purposeful sampling methods, was used to determine the study group (Yıldırım \& Şimşek, 2011) because it saves time and is affordable.

\subsection{Procedure}

I decided to use metaphors as a data collection method since this method helps a person to indicate thoughts which are difficult to indicate otherwise (Visser-Wijnveen et al., 2009). For this purpose, a structured questionnaire was used to determine the metaphors on merit developed by the study group. Participants were asked to write the merit word on the questionnaire together with their perception of what this looks like. Participation in schools was voluntary, and the questionnaire was not distributed to those who did not want to participate.

The data were analyzed using the NVIVO qualitative research program. An inductive content analysis technique was used in the analysis process. The purpose of inductive analysis is to reveal the underlying concepts of data through coding, and the relationships between these concepts (Yıldırım \& Şimşek, 2011). In this context, firstly, the data were coded, and themes were created based on the relationships between the codes. Then the metaphorical analyzed used by the participants were analyzed metaphorically (Tepebaş11, 2013). Direct quotations were also included to reflect the views of the participants in a striking manner. In addition, codes such as K01 were used for the participants in order to hide the personal identities of the participants during the data analysis process.

During the analysis of qualitative data, a road map was created by the researcher based on the conceptual framework of the research and the research questions and the criteria and thematic framework established to ensure harmony and coherence in the analysis of the data. In the analysis, all data were analyzed together using the NVIVO qualitative research program, according to the determined road map. This process carried out during the analysis phase is important for both validity and reliability of qualitative data.

Following the analysis process of the researcher, the codes and themes obtained were shared with another expert. After consensus was reached between the researcher and the expert, the codes and themes were revised. This is a factor that increases the reliability of the research. The research findings were then shared with a manager and a teacher who were asked to confirm whether their views were correctly reflected. It was seen that the opinions of the participants and the results of the research coincided with the findings. This is considered as an internal validity factor. In addition, a clear presentation of the research process, archiving of raw data, and being open to audit if deemed necessary increase the reliability level of the study (Yıldırım \& Şimşek, 2011). Finally, the participants were coded as "Px" in reference to the study ethical considerations 


\section{Results}

The codes obtained regarding the concept of merit after the analysis of the data were collected under the following ten themes: (i) suitability to tasks, (ii) being fair, (iii) diligence productivity, (iv) indispensability, (v) being open for development, (vi) integrative, (vii) being talented, (viii) career steps, (ix) authenticity, and $(x)$ visionary (guiding). In this section, the findings belong to the each theme was presented.

\subsection{Suitability to Tasks}

In the context of suitability to tasks theme, the participants mostly used the driving license, dress, sun, apple, and key metaphors for merit concept. When these concepts used in the metaphorization process are analyzed semantically, it suggests that the concepts of suitability, competence, trust, and maturity are perceived with merit. Some participants likened merit to a driving license by saying that he/she should have received the necessary training and emphasized the competence of merit employees and the necessity of receiving the necessary training for the work to be done. For example, one of the participants stated: "Driver's license: It's like asking someone who doesn't know how to drive to sit behind the wheel and drive. He must be competent" (P127). Another participant, P14 stated "Dress: A person is wearing the right, proper and appropriate dress," saying that merit looks like a dress and merit employees' suitability to the job they choose, so the correct level of merit will increase. Besides, P135 stated: "Sun: The person who is merited illuminates his surroundings like the sun. He supports people in his place with his warmth and light, becomes a source of trust." They likened merit to the sun and emphasized that people would be safer where merit exists.

On the other hand, P150 stated: "Apple: A ripe apple, an apple that has been cut off without a taste. The uneducated, unmerited manager is like a raw fruit." Participants who draw similar concerns compared merit to an apple and stated that merited employees should first reach the required maturity. Similarly, P39 compared the merit to a key by saying "Key: We can open the door if the appropriate key is found" and stated the importance of appropriate people working in the appropriate places for the institutions. Another participant, P39 stated: "Medal: It is given to the person who meets the word literally (worthy, competence, suitability)," and compared the merit to the medal and emphasized suitability for the task.

Table 1.

The results of metaphoric analysis of theme of suitability for task

\begin{tabular}{llc}
\hline Theme & Codes (metaphors) & $\boldsymbol{n}$ \\
\hline & Driving License (6), Dress (6), Sun (4), Apple (2), Key (2), Medal & \\
& (2), Measuring Cup (2), Strainer (1), Hawk (1), Seesaw (1), & \\
Suitability to Tasks & Building (1), Shoes (1), Teapot (1), Dough (1), Cup (1), Crown & 44 \\
& (1), Water Center (1), Piano (1), Handyman (1), Shepherd (1), & \\
& Horse (1), Armchair (1), Fashion (1), Nut-Screw Relation (1), & \\
& Chess Piece (1), Teacher (1), Tweezers (1)
\end{tabular}

\section{2. Being Fair}

Being fair theme included participant responses mostly included metaphors of scales, mother, ruler, father, and video camera to explain the merit concept. These concepts used in the metaphorization process suggest that the concept of justice is perceived with merit. P48 indicated "Scale: Balance is important in every period of life. We can solve all problems if balance and justice are given importance. Administrators who believe in the rights and law that are balanced in their environment can be successful," and likened merit to scales and emphasized that justice is the basis of merit.

Some participants likened merit to a mother by saying that they tries to balance in a conscientious way without giving up and stated that merit is equality and mentioned the necessity 
of being fair to every individual working in the institution. For example, participants stated the following:

"Mother: What is expected from a good mother is that she does not distinguish between her children with different characteristics and guides them to achieve the desired goals by using different methods" (P33).

Some participants also stated that the assessment does not discriminate in real terms within the framework of rights law, and likened merit to mother, and expressed merit as non-discriminating. For example, P12 underlined: "Mother: I look like a mother. Because the mother knows the importance of the deserving son better" (P12).

P65, on the other hand, stated: "Ruler: To be able to make accurate and real measurements." They likened merit to a ruler and stated that merit is needed to achieve real results. Another participant (P114) stated, "Glass: Transparent, pure, necessary, visible from the inside," and compared merit to glass and emphasized the necessity of merit executives to have a transparent management understanding. As another example, P59 stated: "Panoramic Camera: Resembles merit to the panoramic camera by saying that the environment uses objective data by observing the employees objectively," and stated that there will be objective measurements and evaluations where there is merit.

Table 2.

The results of metaphoric analysis related to being fair theme

\begin{tabular}{llc}
\hline Theme & Codes (metaphors) & $\boldsymbol{n}$ \\
\hline \multirow{3}{*}{ Being Fair } & Scale (8), Mother (7), Ruler (3), Video Camera (2), Father (2), & \\
& Glass (2), Rumi (1), Orchid (1), Conscience (1), Mirror (1), Field & 33 \\
& (1), Angel (1), Lectern (1), Circle Center (1), Digital Camera (1) & \\
\hline
\end{tabular}

\section{3. Diligence-Productivity}

In addition to the concepts presented above, the participants used the metaphors of ant, bee, gardener, and boomerang instead of merit concept (see Table 3). When these concepts used in the metaphorization process are analyzed semantically, it suggests that the concepts of diligence, productivity, discipline, and performance are perceived with merit. For example, P123 stated: "Ant: An employee, a laborer, an individual who knows his/her responsibility behaves in accordance with his/her job," and likened merit to an ant and emphasized the diligence of merit employees. Also, P25 indicated: "Bee: Planned, scheduled, regular people who know their jobs like the bee are required to deserve," while P44 stated: "Bee: Bees have achieved social success through regular and systematic work," and compared merit to the bee and emphasized that having merit requires a systematic work.

In a response representing a different metaphor, P163 stated: "Gardener: If the gardener sows the product to be cultivated and gives the anchors, water and fertilizer in time, he can take the desired yield," and likened the merit to the gardener and expressed the strong relationship between merit and labor. Another participant P2 stated: "Pen: Even if it is to produce, develop or invent something, the design phase will not be without pen. The way your ideas will surely pass through the pen. Without merit, there would be no success," and likened merit to pen and emphasized that merit employees would be productive.

Some participants called it a fast and powerful tool and compared merit to a rocket and stated that merit employees form the basis of the success of the institutions. For example, one of the participants stated: "Rocket: Just as a rocket takes the space shuttle on its back and brings it into space after a challenging process and makes the space shuttle fulfill its tasks and succeed" (P37). Merit is also a means to take institutions on their back and lead them to success. 
Table 3.

The results of metaphoric analysis related to diligence-productivity theme

\begin{tabular}{llc}
\hline Theme & Codes (metaphors) & $n$ \\
\hline & Ant (7), Bee (3), Gardener (2), Pen (2), Boomerang (2), Grass (1), & \\
Diligence & Cheetah (1), Smart Phone (1), Vehicle Fuel (1), Quality Fuel (1), Air & 27 \\
Productivity & (1), Runner (1), Success (1), Weightlifter (1), Medallion (1), Rocket (1) & \\
\hline
\end{tabular}

\section{4. Indispensability}

In the context of the indispensability theme, the participants adopted water, soil, medicine, brain, and cogwheel metaphors in their analogies about merit concept (see Table 4). Semantic analyzes suggested that the concepts of indispensability and necessity are perceived as a merit. For example, P166 stated: "Water: The source of life. On the other hand, the meritorious person," and likened merit to water by emphasizing that merit is a prerequisite for an institution. Some participants likened merit to land and emphasized that merit is indispensable for a system, just as land is indispensable for humanity. For example, P88 indicated: "Soil: Whatever you give to the soil, it gives you back. It is a kind of reflection of justice" (P88).

Another participant, P170 asserted that, "Soil: No matter what you plant in the soil, the soil will not behave ungratefully after showing the necessary attention. He will do his job properly." Besides, P42 said, "Drug: You know that you need it, but you can't always find it everywhere," and likened merit to medication and emphasized that merit is essential for organizations to sustain their lives in a healthy way.

As another example, P174 stated: "Brain: Just as a body does not work without a brain, even without merit, a person is useless. A non-merit manager said he would do more harm than good," and compared merit to the brain and stated that merit is the most important organ of an institution. In addition, P162 stated, "Impeller: If one of the teeth of the impeller is defective or missing, it means that the impeller does not rotate or work properly." By saying merit needs every wheel in the system to work, the participants compared merit to a wheel and emphasized the need for merit employees to work effectively in organizations.

Table 4.

Metaphoric analysis results related to indispensability theme

\begin{tabular}{lll}
\hline Theme & Codes (Metaphors) & $\boldsymbol{n}$ \\
\hline & Water (4), Soil (3), Medicine (2), Brain (2), Impeller (2), Backbone & \\
Indispensability & (1), Artery (1), Salt (1), Health (1), Pastry Cream (1), Basic Need & 25 \\
& (1), Pedestal (1), Quitting smoking (1), Coffee table (1), Table (1), & \\
& Sun (1), Ship (1) & \\
\hline
\end{tabular}

\section{5. Being Open for Development}

Besides the presented themes, some of the common metaphors that the participants mostly used were tree, computer, and children in their analogy of merit. Metaphorization process revealed that the concepts of being open to development are perceived merit. For example, one of the participants stated:

"Tree: We can compare the fact that people are in the places they deserve according to their abilities, diligence, point of view, and the right climate, the right soil, and very healthy fruits. These trees are good for them and can be quite useful for those around them" (P15).

The participant likened merit to a tree and stated that merit people can affect both their institutions and their environment. Another participant compared merit to the computer by saying that it increases the suitability according to the time and needs of the computer and emphasized that the merit level of merit employees will increase as much as their suitability to the job they choose. For example, P147 coded participant stated: "Computer: Open to the development of time (P147)". Another participant likened merit to the book by saying that it makes you suitable and 
worthy to be given a different job and stated that having merit and being open to development proceed in parallel. For example, P156 coded participant stated: "Book: You learn as you read. You learn as you learn. As you evolve, you use your language and knowledge". P74, on the other hand stated that "Child: I can look like a new child. With an uninterested and incompetent irrelevant teacher, the child will not be successful, and with a successful teacher, he will shine like a star." Besides, P99 indicated that "Larva: Larvae become mature by metamorphosis, differentiation in the development of progress;" since he resembled merit to larvae.

Table 5.

Metaphoric analysis results related to being open for development theme

\begin{tabular}{llc}
\hline Theme & Codes (metaphors) & $n$ \\
\hline Being Open for & Tree (8), Computer (3), Child (2), Book (1), & 16 \\
Development & Larva (1), Seed (1) & \\
\hline
\end{tabular}

\subsection{Integrative}

In the integrative theme, one of the metaphors that participants used commonly was the concept of nature. The analysis showed that integrative concepts are perceived as merit. Some participants likened merit to nature by saying that, like nature, it contains all living and inanimate beings and makes it possible to live together in balance, emphasizing that the management of all stakeholders in the organization is made in balance. For example, P49 coded participant stated: "Nature: Merit should be like Mother Nature which contains all living and non-living beings and enables them to live together". Another participant likened merit to the cell and stated that there is not only merit but merit with equality, a career, fair and adequate wages, and in-service evaluation principles. For example, P104 stated that: "Cell: Although it does not have a lot of features alone, when combined with other similar values (quality education, proper character, etc.), it forms a complete and smooth working whole". Also, another participant likened merit to a queen bee by saying that they was a bee who watched, like a queen bee coordinating and protecting her employees at the same time. He/she emphasized that the merit of school administrators can implement all management processes as a whole. For example, P36 indicated "Merit should be like a queen bee".

Another participant, P161 stated: "Forest: Trees provide the necessary oxygen for the survival of other living creatures. It also cleans the environment, air, and prevents disasters indirectly (landslides, etc.). People with merit are exemplary in helping other people." Similar responses likened merit to the forest and emphasized the importance of harmonious functioning of all elements of the school.

Table 6.

The results of metaphoric analysis of integrative theme

\begin{tabular}{llc}
\hline Theme & Codes (Metaphors) & $\boldsymbol{n}$ \\
\hline & Nature (2), Sky (1), Cell (1), Jackal-Wolf Relationship (1), Forest (1), & \\
Integrative & Queen Bee (1), Arrow (1), Sponge (1), Circle (1) & 10
\end{tabular}

\subsection{Being Talented}

In their metaphors regarding the merit concept, some of the participants used the concepts of lion, duck and pilot. When these concepts used in the metaphorization process are analyzed semantically, the ability to make decisions and to adapt to each condition suggests that concepts are perceived with merit. In this regard, P183 stated:

"Lion: I see merit as a lion because he is confident, catches his prey in some way and makes his foresight good, captures the environment. The person who catches the merit is like a lion, he is not afraid of anything and does not worry. The person who is afraid and worried cannot make the right decision, even if he does it, he said that it would not be very healthy."

In his comments, P183 affiliate merit with the lion and when the employees have merit they can make their decisions more accurately. Another participant likened merit to a pilot and emphasized 
that merit employees know how to manage their organization even under difficult conditions. For example, P3 stated that: "Pilot: The pilot knows how to land his plane in any weather condition." Whereas P77 linkened merit to the duck by asserting that "Duck: because it adapts to all kinds of climate conditions (living in the air, on land, in water)," and emphasized that people will be safer where there is merit and P19 indicated: "Everyone should do the work he deserves. He said that the job would be beneficial to both the person and humanity, and he compared the merit to the horse rider and swordsman and expressed the importance of merit employees to be competent."

Table 7.

The results of metaphoric analysis on the theme of being talented

\begin{tabular}{lll}
\hline Theme & Codes (Metaphors) & $\boldsymbol{n}$ \\
\hline & Lion (4), Team Captain (1), Pilot (1), Crab (1), Duck (1), Who & \\
Being Talented & Enjoys Horse Riding His Sword Girded (1), Seal (1) & 10 \\
\hline
\end{tabular}

\subsection{Career Steps}

Responses regarding to the career steps revealed that the concepts of a ladder and Maslow's Hierarchy of Needs Pyramid mostly referred by referring the merit concept. For example, one of the participants stated: "Stairs: Career steps. A ladder moves people up or down according to their characteristics (P87)." Another participant associated merit to a ladder and stated that there is an important and inseparable relationship between merit and career steps: "Ladder: If used correctly, it would raise the whole society up, and down if it is used incorrectly (P69)." P8 stated: "Maslow's Pyramid: Once an individual excels in one category, he or she can move on to other levels." P43 also indicated that: "Maslow's Pyramid: We can resemble merit to Maslow's Pyramid. Basically, it starts as a candidate teacher and continues as a teacher, assistant manager and director as the steps increase in the profession." The analysis of these responses showed that the participants likened merit to Maslow's Hierarchy of Needs Pyramid and stressed the importance of merit-based transitions of school management levels. In order to reach the goal of a qualified school, the respondents emphasized that the administrators first evidence the assistant principal features and then they can reach other levels, such as directorate and branch officer.

One of the participants likened merit to Turkish coffee and emphasized the importance of progressing to the next step by gradually gaining experience in employee career steps. P110 stated: "Turkish Coffee: I liken Turkish Coffee to be cooked on low heat. Cold water and slowly cooked over low heat, the coffee is full consistency and delicious".

Table 8.

The results of metaphoric analysis related to theme of career steps

\begin{tabular}{llc}
\hline Theme & Codes (metaphors) & $\boldsymbol{n}$ \\
\hline Career Steps & $\begin{array}{l}\text { Ladder (5), Maslow's Pyramid (2), } \\
\text { Turkish Coffee (1) }\end{array}$ & 8 \\
\hline
\end{tabular}

\subsection{Authenticity}

As can be seen in Table 9 is examined, the participants mostly used the concepts of car and flower in their analogy to express the merit concept in the context of authenticity theme. In this sense, one of the participants stated: "Vehicle: I liken merit to the latest model car. He likened merit to a car in order to achieve his goals more easily and with high quality (P83)" and emphasized the importance of being original for institutions to be fast-paced and of high quality. Some of the participants likened merit to a flower and emphasized the importance of making the necessary arrangements to create a positive organizational culture and climate. For example, P133 indicated:

"Flower: I can compare it to a flower that is magnificent and has a unique beauty. A quality seed, careful care. It is a vivid flower that gives endless aesthetics and beauty to the environment in which it is located" (P133). 
Table 9.

The results of metaphoric analysis on the theme of authenticity

\begin{tabular}{lll}
\hline Theme & Codes (metaphors) & $\boldsymbol{n}$ \\
\hline Authenticity & Car (4), Flower (2), Fruit (1), Pen (1) & 8 \\
\hline
\end{tabular}

\subsection{Visionary (Guiding)}

As final theme in the analysis, responses related to visionary revealed that the participants mostly used the compass, light, torch, and solar concepts to express merit. One of the participants, P13, likened merit to a compass by saying that truth, honesty, reality, and righteousness show almost that side and stated that the organization will always go forward under the leadership of merit managers. Another participant used the light metaphor to express merit by saying that we cannot know where we are going, and they emphasized that it would be easier for organizations with merit to achieve their goals. One participant likened merit to a torch and emphasized that the merit manager would always guide his employees. He stated: "Torch: We can think of it as a torch that illuminates the area. The merit manager is the guide and the developer, radiates light and destroys ignorance. However, in any institution or job, the executive who does not have merit will think only of his/her own interest, and there will be no chance of democratic life to travel at the bottom of justice, rights and welfare" (P70)". Finally, one participant likened merit to the sun by saying that they sheds light around him as he illuminated and emphasized that the merit manager would mentor his employees: "Sun: Radiates heat and light around. Merit leads to better surroundings. In the face of merit, dark feelings can be enlightened. Negative becomes positive (P41)".

Table 10.

The results of metaphoric analysis on being visionary (guiding) theme:

\begin{tabular}{lll}
\hline Theme & Codes (Metaphors) & $n$ \\
\hline Visionary (Guiding) & Compass, Light, Torch, Solar & 4 \\
\hline
\end{tabular}

\section{Discussion and Conclusion}

According to the results of the research, the most emphasized feature of merit individuals was their suitability for the task. Participants emphasized the competence of the employees in terms of suitability of the qualified employees. In this context, it is stated that the necessary training should be taken for the work to be done. In fact, this shows that vocational training or the vocational training process is essential for merit. In fact, Akbaşlı and Diş (2019) state that one of the personality characteristics of leading school administrators is to give importance to professional development. However, increasing the merit level of employees is accepted as an indicator of their suitability for the job. In fact, this situation confirms the principle of "a man for a job, not a job for a man."

In a study conducted by Şahin and Sabanc1 (2018), the second most emphasized theme in metaphoric perceptions developed about school administrators is expertise. Therefore, it can be possible for the qualified managers to be suitable people by being experts in their fields. In addition, the fact that employees feel more secure in organizations based on merit is one of the important results of the research. For this reason, it is important for organizations to work in suitable places for the appropriate people. In the study of Ergül (2017), it is stated that Rumi also emphasized that statesmen and administrators should benefit from the consultancy of competent and expert people.

The second most emphasized merit feature is talent. Participants expressed this feature by emphasizing that merit employees can manage organizations even under difficult conditions. In this respect, it is stated that merit people are competent people. They also said that competent people can make the right decisions. Talent is one of the fundamentals of the merit system (Castilla \& Benard, 2010). Considering that talent is obviously essential for the future of organizations in a 
global market (Brown \& Tannock, 2009) and that management is a decision-making process, it can be said that merit employees are very important for the lives of organizations in this context.

The third highlight of merit is diligence. It was stated by the participants that industrious people are productive and are performers. In this context, it can be said that there is a strong relationship between merit and labor and merit and performance in organizations. The most emphasized fourth merit feature is fairness. Participants emphasized that justice is the basis of merit. In addition, merit is associated with equality, non-discrimination, transparent management, and objective evaluation. Similarly, Özdemir (2013) studied the relationship between fairness and merit in school principals, and loyalty and effort in teachers, and concluded that employees have the ambition of loyalty and work if rights and justice are important to managers. At the same time, Kiycak (2014) states that, thanks to the understanding of fair management of a qualified manager, a large mechanism called the state can function in a healthy way. Ergül (2017) supports the results of the study by stating that paying attention to merit and competency is related to the realization of justice according to Rumi.

The fifth highlight of merit is indispensability. The participants emphasized that one of the prerequisites for an organization is merit. In particular, this situation has been expressed with the words "just as land is indispensable for humanity, merit is indispensable for a system." Merit was likened to medication by another participant, and it was stated that there is a need for organizations to continue their lives in a healthy way. Merit is also explained as being open to development. In this context, the participants stated that merit people can influence both their institutions and their environment. As a result, it can be said that it will be easier to achieve success with qualified employees. Similarly, Akbaşlı and Diş (2019) mentioned that leading school administrators should have the personality characteristic of being open to innovation.

Another important result of the study is the explanation of merit with its integrative feature. The participants emphasized the concept of balance in organizational management and emphasized that merit people should integrate all employees. In addition, not only merit but also systematically in accordance with merit, equality, career, a fair and adequate wage, and in-service evaluation principles are necessary. At the same time, participants stated that organizational success in the context of the merit concept depends on the ability of school administrators to implement management processes as a whole.

In addition, merit is seen as a means of promotion through career steps in organizations. At this point, it can be said that there is an important and inseparable relationship between career levels and merit. In the study, it is stated that a merit-based system is necessary in the career steps of school administration. As a matter of fact, in a study conducted by Gök (2017), it was emphasized that merit should be taken as a basis in career steps. In the study of Gök (2017), it was stated that there should not be a transition to a director without being an assistant manager and that there should not be a branch manager without being director. He also emphasized the importance of merit-based transitions. In addition, the importance of progressing to the next level by gaining experience gradually and emphasizing the career steps of the employees was highlighted.

Another important feature for organizations is the originality of the studies and their being visionary. In the research, participants see this as the characteristics that merit individuals should have. It was emphasized that the organization will always go forward under the leadership of merit managers, and it will be easier for the organizations to reach their goals. Furthermore, it is stated that a qualified manager should always be a mentor to his/her employees. Being a visionary is also seen as an important leadership quality by Akbaşlı and Diş (2019), in terms of the qualifications required by the leading school administrators. In this sense, the fact that merit people are visionary suggests that leaders should also be merit people. Indeed, in the same study of Akbaşlı and Diş (2019), another of the leadership competencies is to have merit.

On the whole, school administrators explained merit in terms of suitability to the task, being capable, fair, indispensable, open to development, diligent, integrative, focused on career steps, authentic, and visionary. In literature, it is seen that the increase in professional levels is evidenced 
by people with intelligence, diligence, and talent (Karagözoğlu, 2013; Leblebici, 2008). Although merit is often perceived as the sum of intelligence and skills, it is also seen as a process by which educational qualifications or educational skills are documented. Merit has become a means of setting and achieving standards as a means of reaching appropriate, respected, and equitable professional positions and progressing professionally (Young, 1970). In Turkish, merit is defined as the suitability of a person to be given a job and the status of worthiness (TLA, 2019).

Different from the existing literature, the perception of the participants of the current study towards merit concept highlighted that merit people are intelligent, hardworking, and talented. They also have the characteristics of being fair, open to development, and they are original and visionary, integrative, and indispensable. Already, talent and diligence were two of the key factors for rising through the merit system (Littler, 2017).

As a result, the participants considered their own personal positions by expressing merit concept and associated it with management rather. Therefore, the metaphors attributed to merit in the study actually appear to be the characteristics of competent managers. Besides these conclusions, the study has some limitations to be considered. First, the results reflect the opinions of the 185 participants. In this sense, the results cannot be generalized because of the nature of the qualitative studies. Second, the conceptual opinions on merit were only investigated via metaphors. As for future research, merit principles can be studied for school administrators. Moreover, conducting studies related to meritocratic behaviors of the administrators are recommended for future research.

\section{References}

Akbaşlı, S. \& Diş, O. (2019). Competencies of school managers as a leader according to teachers' views. International Journal of Leadership Studies: Theory and Practice, 2(2), 86-102.

Akin-Kösterelioğlu, M. (2014). Metaphoric perception of preservice teachers towards the concept of school administrator. Zeitschrift für die Welt der Türken, 6(3), 115-133.

Arnett, R. C. (1999). Metaphorical guidance: Administration as building and renovation, Journal of Educational Administration, 37(1), 80-89.

Arslan, M. \& Bayrakçı, M. (2006). An examination of metaphorical thinking and learning from educational view. Millî Ĕ̆itim Dergisi, 171, 100-108.

Ateş, M. (1995). Public services recruitment systems and policies a review on the implementation in Turkey. Ankara: DPT.

Aykaç, B. (1990). Personel yönetiminde yeterlik ilkesi [The principle of competence in staff management]. Amme İdaresi Dergisi, 23(4), 91-109.

Binbaşığlu, C. (1978). Eğitim yöneticiliği [Education management]. Ankara: Binbaşığlu.

Brown, P., \& Tannock, S. (2009). Education, meritocracy and the global war for talent. Journal of Education Policy, 24(4), 377-392.

Bucaktepe, A. (2014). Ideas on the evaluation of the civil service and civil servants. Gazi University Faculty of Law Review, 18(3), 459-490.

Büyüköztürk, Ş., Çakmak, E. K., Akgün, Ö. E., Karadeniz, Ş., \& Demirel, F. (2010). Scientific research methods. Ankara: Pegem.

Castilla, E. \& Benard S. (2010). The paradox of meritocracy in organizations. Administrative Science Quarterly, 55(4), 543-576.

Diler, K. İ. (2018). The merit principle in public personnel law. [Unpublished master's dissertation]. Institute of Educational Sciences, Ankara University, Turkey.

Ergül, E . (2017). The Merit And Competence Principle In Public Administration From Rumi's Perspective. Ombudsman Academic, 6, 79-105.

Ergun, T. (2004). Kamu yönetimi: Kuram, siyasa, uygulama [Public administration: Theory, policy, practice]. Ankara: TODAİE.

Evcim, U. (2008). The role of metaphors in perception of organizational culture [Unpublished master's dissertation]. Institute of Educational Sciences, Gazi University, Turkey. 
Fraenkel, J. R., Wallen, N., \& Hyun, H. (2011). How to design and evaluate research in education. New York: McGraw-Hill

Gök, R. (2017). The examination of meritocracy and merit based administrator training, appointment, evaluation system and the qualifications of capable administrator in the Turkish education system: A mixed typed study [Unpublished doctoral dissertation]. Institute of Educational Sciences, Antalya University, Tukey.

Gökdeniz, K., Aydemir, V., \& Çağan, S. (2017). Implementatıon of the merıt system in turkısh publıc admınıstratıon after the republican period. Journal of Economics and Management Studies. 6(2), 200-215.

Günay, A. \& Çarıkçı, İ. H. (2019). An investigation on the psychotechnical tests utilised in the recruitment processes of human resources. SDU Visionary Journal, 10(23), 178-194.

Günay, Ö. F. (2005). Türkiye'de kamu yöneticisi nasıl yetiştirilmelidir? [How should public managers trained in Turkey?] Ankara: Turhan.

Hoy, W. K. \& Miskel, C. G. (2010). Eğitim yönetimi [Education administration] (Çev. Edit. S. Turan). Ankara: Nobel.

Karagözoğlu, A. A. (2013). Meritocracy in training and appointment of managers in educational institutions. (Unpublished master's dissertation). Frrat University, Turkey.

Karatepe, S., \& Kurnaz, S. (2019). Merit principle in public management: an evaluation for turkey over great britain example. Erciyes Üniversitesi Sosyal Bilimler Enstitüsü Dergisi, 33(46), 77-104.

Kaya, Y. K. (1999). Eğitim yönetimi: Kuram ve Türkiye'deki uygulama [Education administration: Theory and practice in Turkey]. Ankara: Bilim.

Kiycak, Ö. (2014). As heroes of dissolution century poetry administrators and justice. Electronic Turkish Studies, 9(3), 893-915.

Lakoff, G., \& Johnson, M. (2008). Metaphors we live by. Chicago: University of Chicago Press.

Leblebici, D. N. (2008). A study of revisiting classical period in management sciences. Dumlupınar Üniversitesi Sosyal Bilimler Dergisi, 21, 99-118.

Littler, J. (2017). Against Meritocracy. Abingdon, NY: Routledge.

Özdemir, A. (2013). The relationship between the justice and merit of school administrators on the one hand and the loyalty and effort of teachers on the other. Kuram ve Uygulamada Egitim Yönetimi Dergisi, 19(1), 99117.

Saban, A., Koçbeker, B. N., \& Saban, A. (2006). An investigation of the concept of teacher among prospective teachers through metaphor analysis. Educational Sciences: Theory \& Practice, 6(2), 509-522.

State Personnel Law [SPL]. (1965). State Personnel Law. Official Gazzette (Number: 12056). www.resmigazete.gov.tr

Şahin, A. \& Sabanc1, A. (2018). Perceptions of prospective teachers attanding pedagojical formation courses regarding the school administrators and teachers: a metaphorical study. Turkish Studies, 13(4), 1057-1082.

Şahin, B. \& Şahin, İ. (2016). A suggestion to apply merit system in Turkish administrative system: Turkish national police example. Muğla Sıtkı Koçman Üniversitesi İktisadi ve İdari Bilimler Fakültesi Ekonomi ve Yönetim Araştırmaları Dergisi, 5(1), 98-113.

Şahin, B. (2016). Modern principles of merit of admission and promotion in Turkish personnel system, Çukurova Üniversitesi Sosyal Bilimler Dergisi, 25(1), 231- 242.

Sayan, İ. Ö. (2017). Thinking about the public personnel administration problems and solutions in Turkey. Van Yüzüncü Yıl Sosyal Bilimler Enstitüsü Dergisi, 1(4), 1-7.

Semerci, Ç. (2007). A view to the new primary school curricula with the metaphors relating to "curriculum development", Ç. Ü. Sosyal Bilimler Dergisi, 31(2), 125-140

Sezer, Y. (2003). Exceptional public in terms of the right to enter public service and the principle of merit. Selçuk Üniversitesi Hukuk Fakültesi Dergisi, 11(3-4), 173-193.

Turkish Language Association [TLA]. (2019). Türk dil kurumu sözlükleri [Turkish language association dictionaries]. http:/ / www.sozluk.gov.tr/

Tepebaşılı, F. (2013). Metafor yazıları [Metaphor writings]. Konya, Çizgi.

Tortop, N. (1982). Personel yönetimi [Staff management]. Ankara

Uz, A. (2011). Right to enter public service as a constitutional right and merit principle. İnönü Üniversitesi Hukuk Fakültesi Dergisi, 2(1), 59-94

Yıldırım, A. \& Şimşek, H. (2011). Qualitative research methods in the social sciences. Ankara: Seçkin.

Yıldız, G. (2016). The merit principle in the Turkish public administration. Gazi Üniversitesi Sosyal Bilimler Dergisi, 3(8), 140-180.

Young, M. (1970). The rise of the meritocracy, 1870-2033: an essay on education and equality. London: Penguin. 